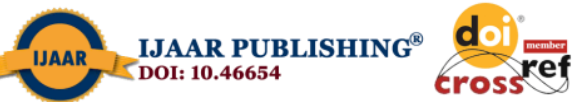

International Journal of Advanced Academic Research (Social and Management Sciences) | ISSN: 2488-9849

Journal DOI: 10.46654/ij.24889849

Vol. 6, Issue 9 (September, 2020) |www.ijaar.org

Article DOI: 10.46654/ij.24889849.s692

\title{
EFFECT OF POLITICAL ENVIRONMENT ON ORGANIZATIONAL PERFORMANCE: A STUDY OF SELECTED SMALL AND MEDIUM SCALE ENTERPRISES IN DELTA STATE
}

\author{
${ }^{1}$ ONORIODE, Omorho Humphrey and ${ }^{2}$ AGBELE, George (Ph. D) \\ ${ }^{1}$ Department of Business Administration and Management, \\ Delta State Polytechnic, Ozoro, Nigeria. \\ E-mail: ${ }^{1}$ onoriodehumphrey@yahoo.co.uk; ${ }^{2}$ georgeashams@gmail.com
}

\begin{abstract}
This paper assessed the effect of political environment on organizational performance with a focus on selected SMEs in Delta State. The objectives of the study are to determine the correlation between political environment and efficiency of small scale enterprises, to ascertain the relationship between political environment and customer satisfaction, and also to assess the relationship between political environment and employee retention. Four (4) hypotheses were tested and research questions were also formulated. Descriptive survey research design was used because a field research was conducted. The research population is 371 that make up the number of workers of the selected industries across the state. A judgmental sampling technique was adopted to pick 356 respondents as the sample size. The study used both primary and secondary data collection. Correlation coefficient was employed for data analysis. The finding revealed that efficiency of SMEs is dependent and sensitive to political environment. Again, stable political environment influences customer satisfaction and also encourages employee retention. We recommend that organizations should be environmentally conscious and constantly monitor and conduct environmental scanning for proper adaptability by business organization.
\end{abstract}

Keywords: Political, Environmental, Organizational, Performance. 


\section{INTRODUCTION}

The political environment is viewed through the legal frame work where the organization operates and this is done through the laws and regulations that guide the operations of the business in question. Political environment exact influence on the performance of firms irrespective of size, but politics is also a component of other external risks and moreover, the political environment is often perceived to be outside the management control, making it difficult to define, predict and align with objectives (Mark and Nwawu, 2015). The conducive and peaceful environment is also a necessity for effective and efficient operation of the business. It is generally believed that political stability results to business stability, while political instability encourages business instability.

Besides, political risk complicates the planning activities of business organizations. Decisions and risks that are associated with politics are also factors that will jeopardize business strategy or severally damage the firms (Demaki, 1999). Risk and instability in politics have created fear and panic in the heart of entrepreneurs over the ages while making investment within and outside country. They continue to express failure in their production and distribution process. Businesses (big and small) function well under a social political environment (Adeusi and Aluko, 2014). Mawoh and Aliyu (2010) postulate that since Nigeria gained independence, the political terrain has been highly unpredictable. They are of the opinion that there is lack of continuity with respect to economic policies, thus long term planning becomes difficult to do. The management of the organization is advised to take note of these challenges, risks on business organization and consult legal adviser on these issue. Ogundele (2005).

Capital availability is not always a problem to so many entrepreneurs but inability to adapt to the business environment as a result of these ever changing variables is a challenge to the success of indigenous business operation. Majority of them are not even informed of the political situation that has hinder business over the years. They are unable to predict the political situation of their immediate environment in which business exists. Some researchers also recommend that experts should be involve in studying the political environment and also help to forecast likely situation politically. External business environment of Nigeria organization impinges upon the operation of a business other than the availability of capital and the ability of the manager or business owners. All things being equal, controlling of the external business environment can be done to some extent and entails and call for constant monitoring and conducting environmental scanning always (Adeoye Elegunde, 2012).

Marthar (1991) suggests that political shift many effect on the part of firms that cause them to renege on commitment to their suppliers, partners or customer. Government policies matters a lot on the political environment. Political reactions to most times depends on policy made. Shift in government policy may also place a multinational firm worldwide strategy at risk by disrupting the production of one components or reducing the market for importing products (Gome and Jeniffer, 2002). Inconsistency in policy making has caused more harm than good in our political environment. Habid and Eurawick (2002) further states that McDonalds worldwide image helped them take a stand against corruption in Russia and Gratchev (2001) reported a similar effect among employees corrupt political environment is likely to impose greater obstacles on domestic firms than their foreign stable political environment enhances growth, and development and also encourage both foreign and local investors.

Any organization that hopes to succeed in any business environment must as matter of 
necessity pay attention to political environment. So many businesses all over the world, especially SMEs have falling apart despite their good intention and objective. Most of them gave bigger percentage of their time and money to rewards and motivation of employees to guaranteed business continuity and success but failed to understand the political terrain. Therefore, this paper examines effect of political environment on organizational performance with a focus on selected SMEs in Delta State.

\section{Statement of the Problem}

The issue of political environment needs to be addressed as far as organizational performance of small scale enterprise is concern to achieve the set goal. The peaceful and conducive political environment of an organization is connected to the success and progress of every organization. The bed rock of every business success is environment. Proper monitoring of the political environment affects the profitability of every business irrespective of the size. Organizations today have attributed their business challenges to be lack of commitment, experience and competency but their poor and nonchalant attitude toward political changes has affected businesses seriously.

The government (policies, rules and regulation) and non-governmental (Wars, extortion, terrorism, kidnapping and strike) political risks has become an issue that has bedeviled the growth, profit and goals of Business organization Andoh (2007). The problem of the study therefore is to investigate if political environment affect the performance of SMEs.

\section{Objectives of the Study}

The main objective of this study is to examine the effect of political environment on organizational performance with a focus on selected small scale enterprises in Delta State. Other objectives are:

i. To determine the correlation between political environment and efficiency of small scale enterprises.

ii. To ascertain the relationship between political environment and customers satisfaction.

iii. To assess the relationship between political environment and employee retention.

\section{Conceptual and Theoretical Framework}

The environment in which business organization operates is a complex, multi-focus dynamic and has a far reaching effect on such organization Eruemegbe (2015). The inability of entrepreneur to predict the political terrain is a contending issue that entrepreneurs are faced with in their daily operation. Aldrich (1979) opines that the environment was made up of stable and unstable homogenous, heterogeneous, rich and poor, complex and simple, unpredictable variables. In the opinion of the author, he beliefs that business environmental factors changes is associated with factors of production and that these environmental influences may be stable over a period of time. Eruemegbe (2015) argues further that political stability has ramification on planning, for example no organization want to set-up business in another country where the trade relationship are not relatively defined and stable. Porter (1980-85) also argues that the central tenets of a firm's competitive advantage rest on the ability of the firm to position and differentiate itself in a given context.

Political hostility, especially in developing countries may not be totally eradicated 
irrespective of the preaching to avoid political violence. Organizations performance will continuously be affected. Pearson, Robinson and Mital (2008) stated that external environment is a factor beyond the control of the firm that influences its choice of direction and action, organizational pattern and processes. According to Watter (2014) the implication of political environment to a business is that the risk emanating from it is a measure of likelihood that the organizations profit may be affected directly or indirectly. Political tensions and heat is created in different ways and by different groups of persons. All these kind of risks can result to violence, directed towards firm's property and employees (Mark and Nwaiwu, 2015). Adeoye (2012) reports that environmental changes are continuously exerting new pressures on company performance and for them to adapt with these changes companies often formulate and implement strategies to recognize and reform the way products are assembled and channeled to final consumers.

\section{Organizational Performance}

Daft (2000) postulates that organizational performance is the organizations capability to accomplish its goal effectively and efficiently using resources. Accomplishment of object by any organization is dependent on material availability. When tools are not made available to worker it becomes difficult to achieve organizational set goals. Richard and Dada (2001) assert that achieving organizational goals and objectives is known as organizational performance. Organizational achievement is measured by the level of performance. Richard and Wade (2001) also stresses that organization success shows high return on equality and this becomes possible due to establishment of good employees performance management system.

Motivation is a key factor in moving small and medium size businesses forward anywhere in the world. Although, it could be intrinsic, such as feeling and satisfaction or extrinsic such as reward, punishment or good achievement. When an employee is satisfied, is encouraged to perform. Athar, et al. (2014) opines that job satisfaction is a major factor to enhance and maintain the overall yield of organization and the job loyalty by efficient service and performance. Ali and Abdiguai (2013) states that working environments is significant related to employee performance and job satisfaction.

Performance can also be examined through its leadership styles. To increase performance of an organization, the leader should be able to promote skills, new ideas and stimulate the subordinates to challenge their own value system and improve their individual performance (Hurduzen, 2015). Acceptable leadership style makes employee utilize the potentials. The author further stresses that organizational performance is the transformation of input into outputs for achieving certain outcome. Organization with more control over resources is likely to have the most influence on the performance of the workers (Scott and Davis, 2007).

Nnamani and Ajaju (2014), argues that organizational performance is a very significant factor affecting profitability of organization. Corina et al. (2011) further states that the concept of organizational performance be very common in the academic interactive, its definition is difficult because of its many meaning.

The ability of an organization to develop his team work force is another way to assess it performance level. Certain goals or objectives may not be accomplished unless by working together. Effective leadership method is one of the most essential elements of good teamwork. The terms leader should have the ability to create and influence working environment 
positively and motivate and encourage the team group to take a positive approach to work and be highly committed.

\section{Small and Medium Scale Enterprise (SMEs)}

Most of Nigeria business firms are still small and independently owned and separated by small business proprietors, and that small business firms are the backbone of free enterprise which this country operates (Chukwma, 1999) so many industries that is swimming today falls within, the category of small scale. Although according to Aborode (2005), in a global context a general definition of small scale of operation is not easy, but within boundaries, it might be relatively easier. The term entrepreneur and small business owners are sometimes used interchangeably (Ngige, 2016), Alaezi (2009) states that a small business owner may not necessarily be an entrepreneur, although an entrepreneur can be a small business owner. There is a divergent in people's opinions about what exactly are small enterprises.

In view of the inconsistency and divergent ideas over small scale business, we shall attempt to look at what is a small scale business using definitions given by some Nigerian institutions (Nwaorgu, 2008).

The Central Bank of Nigeria (CBN) credit guidelines number 25 of 1991, defines a smallscale business as any working capital does not exceed five million naira.

Also Central Bank of Nigeria (CBN) refers to small scale business as any business whose annual sales volume and turnover is less than $\$ 500,000$ and employed less than 10 .

The companies and allied matters Act (CAMA) No.1 of 1990 section 37 (2) sees a small business as a company whose Net Asset is not more than one million Naira. According to Nwaorgu (2008), small business today in any not be small tomorrow, and a small business to one person many not be small to another person. The issue is that some businesses in our country today fall within the small and medium scale enterprises. As a result, adequate attention should be given to small scale business owners to encourage productivity.

\section{Theoretical Framework}

This study is built on the negative theory of customer satisfaction. Customer satisfaction is one of the variables this study is built on. The theory was introduced into the customer satisfaction literature by Anderson (1994). The theorist postulates that when expectations are strongly held, users will respond negatively to any disconfirmation.

Therefore, dissatisfaction will occur if perceived performance is less than expectation or if perceived performance surpasses expectation. The theorist idea was that customers has expectations in terms of quality and quantity of goods and services, time delivery and place of delivery and that anything short of these led to their dissatisfaction and negative response. Again, for manufacturing organization to satisfy its customer demands is largely dependent on the political environment situation of that organization. Political crises disturb flow of businesses in our environment. In other words, stable political environment encourages customer satisfaction.

\section{Theoretical Literature}

\section{Efficiency}

Organization efficiency measures relationship between inputs and outputs or how 
successfully the inputs have been transferred into outputs Low (2000). As far as management is concerned, before we can focus on doing things efficiently, we need to be sure we have found the right things to do Idemobi (2010). Efficiency means doing things well. So many firms today perform below expectations because they lack that managerial skill (efficiency) that enables them to meet the set standard. This idea emphasizes that a plan is profitable when it makes meaningful to purpose and objective as offset by the cost and other unsought consequences required to formulate and operates such plan Olusanya, Awotungade and Ohadebere (2012). In every organization irrespective of the size no employee can be efficient under unconducive political environment.

Many organizations have complained time without number that employee performance is below expectation after going through series of training and workshop. Knowledge acquired is not enough for the organizational efficiency. To a very large extent the efficiency of every organization is dependent on the business environment condition. When there is political stability in our business environment, we should expect peaceful atmosphere that results to meaningful productivity. Inconsistency in policy making has caused more harm than good in our political environment. Organizations have been working to improve their productive efficiency despite political risks in our environment. According to Oyebanji (1994), a peaceful political environment enhances growth, development and also encourages both foreign and local investor.

\section{Customer Satisfaction}

Ecker (2007) posits that satisfaction is the quality of the product, services, price performance ratios as well as when a company meets and exceeds the requirements of the customer. So customer's satisfaction is a measure of firm customer base in terms of size, quality and loyalty. Meeting customer's expectations leads to customers' satisfaction. This may be in form of service or product delivery. Customers always specifications with their manufacturing, the types, size quality and quantity of products needed at the time and place goods should be delivered. Manufacturer ultimate desires are to make sure they meet their customer loyalty to them. Customer loyalty and product repurchase are as a result of customer satisfaction (Ecker, 2007). A customer may not repeat a purchase when his needs are not met by the suppliers.

Non obstruction in the supply chain is made possible in an environment that is risky and crisis free politically. There might not be room for customers to think of alternative purchase when there is real desire satisfied. Purchasing the needed product without making another or alternative choice is customer loyalty Wyse (2012). Customer satisfaction leads to customer loyalty and sincerity and this in turn leads to repeat purchase. According to Allen and Willburn (2002), Tuli and Bharauwaji (2009), customer loyalty is often manifested in repeat purchases. The main focus of company today is to satisfy the customer which has an impact on the competitiveness of an enterprise ( $\operatorname{Rad}, 2008)$. Customer satisfaction is connected to political stability of the business environment. In fact better management of political environment i.e directly related to customer satisfaction.

\section{Employee Retention}

Addressing the issue of political environment, the retention of employee need to be considered also. The retention of employee has become a contending issue that many organizations are faced with worldwide (Tizazu, 2015). The kind of workers an organization retains tells the performance expectation. Sutherland (2004) contends that companies with 
high quality human resources perform a better and deliver higher and more consistent to shareholder.

Organization should retain it valuable employees and employees are organizational assets who help in providing innovative, advantageous and creative solution to organizational problems (Daisy, 2003). An organization that is unable to retain its valuable employee is readily to lose valuable customer also. Good employee attract reasonable number of investors to organization and political environmental risk and instability that has chased employees away must be handle very seriously by every manager to guarantee the continuous stay of this reliable workers. Thus, the resignation of potential workers, who are considered as human capital, is an important issue that has a negative impact on the efficiency, effectiveness and general performance of an organization (Harun, 2010). Irrespective of external distractions, to organizational performance, the retention of employee can also be encouraged in several ways. Career development means creating opportunities for promotion and providing opportunities for training and skill development that encourage employees to improve their potentiality on the internal and the external labour market (Meyer and Smith, 2003). According to Armstrong and Murlis (2007), how an employee is appreciated or valued and company's expectation can be expressed by the working environment. Furthermore, avoiding employee turnover would ensure the achievement of company objectives, customer satisfaction and effective succession planning (Mello, 2007).

\section{Empirical Review on Political Environment}

Ahmad et al. (2012) assessed factors influencing an entrepreneur performance in Pakistan. Correlation co-efficient and SPSS was used to analyze data. The finding show that access to finance, public and private partnership, lack of training and education, stress., lack of motivation and lack of political stability are significantly related with the growth of small scale enterprises. Mark and Nwaiwu (2015) carried out a study on the impact of political environment on business performance in Nigeria. In this research, summary research design was used. Political environment was measured as the degree of political Instability and absence of violence while business performance was measured by the profitability of the companies for the period 1999 - 2013. Analysis of data was done through SPSS ad regression methods. The result shows that political environment has a significant impact on business performance. In fact, the result revealed that there is a correlation between political environment and organizational performance. An empirical study was also carried out by Mohammed and Nzelibe (2013) to assess the performance of SMEs as a tool for wealth and employment creation in Nigeria. Financing, anticipated political environment and lack of management skill was used as the factors that influenced the performance of SMEs. Data collected through questionnaire and regression analysis model was used to text or analyzed the hypothesis. To results suggested that there is an association or correction between the perceived political environment and performance of SMEs and lack of management skill affect and influenced the performance of small and medium scale enterprises in Nigeria.

Chittithaworn et al. (2011) in their work investigated the factors that affect the success of SMEs in Thailand. They highlighted the influencing variables to include management and know-how, doing business and cooperation, product and services, resources and finance, strategy and external environment. Data collated through questionnaire and ordinary least square (OLS) was used to measure or test the hypothesis under study. There was an indication that Macro element is positively related to the business success of SMEs in Thailand. Furthermore, in a study conducted by Muzenda (2014) investigated the concept 
model for the measurement and assessment of performance of tourism sector of SMEs in South-African. Entrepreneur attitudes, firm characteristics and macro environment were used in the study as the factor that influenced or affect SMEs performance. Chi-square and SPSS were the tools used for data analysis. The finding indicated that a significant relationship existed between entrepreneur attributes firm characteristics, external environment and SMEs performance.

Kinyua (2014) empirically looked at factors affecting an entrepreneur performance in Jua sector in Nakuru Town of Kenya. The data was collected through primary source. Data collected was analyzed descriptively and inferentially and also it was presented through figures, tables and percentages. The findings indicate that access to finance had the potential to positively affect performance of SMEs management skill, macro environment factors significantly affect the performance of SMEs, but infrastructural did not significantly affect the performance of SMEs

\section{Methodology}

The study covers four (4) registered paint industries and three (3) plastic industries on the 2019 business directory edition of ministry of commerce and industry delta state with a population size of three hundred and seventy one (371) including the owners of the companies and their employees.

The breakdowns of the population of the selected enterprises are stated on the table below.

Table 3.1 Population Size

\begin{tabular}{|l|l|c|}
\hline \multicolumn{1}{|c|}{ S/N } & \multicolumn{1}{|c|}{ Enterprises } & Population Size \\
\hline 1. & Advanced coating technology, Effurun. & 50 \\
\hline 2. & Carmelite industries Agbor. & 65 \\
\hline 3. & Hosanna paint industry & 43 \\
\hline 4. & Joel industries Ogwashi-Uku & 59 \\
\hline 5. & Kaddara plastic, Effrun. & 47 \\
\hline 6. & Unity plastic, Agbor & 45 \\
\hline 7. & Plasticman Enterprises Patani & 62 \\
\hline & TOTAL & 371 \\
\hline
\end{tabular}

Based on the population size of the study (371), we adopted judgmental random sampling technique to pick a sample size of three hundred and fifty six (356) respondents. The hypotheses formulated were tested with correlation analysis using Pearson Product Moment Correlation Coefficient to analyze the data collected. This coefficient enables us to determine the strength of the relationship between two variables - dependent and independent variables.

\section{Analysis and Discussion}

The tables represented below are the results of the research conducted on the relationship existing between the variables in the selected small and medium-size enterprises, Delta State. In testing the hypotheses, correlation co-efficient was used. 


\section{Hypotheses I}

$\mathrm{H}_{0}$ : There is no significant relationship between political environment and efficiency of small scale enterprise.

Note: The percentage of the political environment will be represented by (x), while that of the efficiency, customer satisfaction and employee retention will be represented by $(\mathrm{y})$. The coefficient of correlation will be represented by (r).

Table 4:1: Summary of Percentage Score for Political environment.

\begin{tabular}{|r|l|c|c|c|c|c|}
\hline & \multicolumn{1}{|c|}{ Variables } & SA & A & U & D & SD \\
\hline 1. & Risk and Business Performance & 2 & 4 & 2 & 1 & 1 \\
\hline 2. & Crisis in Business Environment & 1 & 2 & 0 & 2 & 1 \\
\hline 3. & Instability in our Environment & 1 & 3 & 2 & 1 & 1 \\
\hline 4. & Kidnapping Challenges & 1 & 2 & 3 & 1 & 0 \\
\hline 5. & Killing Challenges & 1 & 2 & 4 & 1 & 2 \\
\hline & Total & 6 & 13 & 12 & 6 & 5 \\
\hline
\end{tabular}

Source: Field Survey 2020

Table 4:2: Summary of Percentage Score for Efficiency.

\begin{tabular}{|c|l|c|c|c|c|c|}
\hline & \multicolumn{1}{|c|}{ Variables } & SA & A & U & D & SD \\
\hline 1. & Conducive Environment & 1 & 2 & 1 & 1 & 1 \\
\hline 2. & Motivation & 1 & 2 & 2 & 2 & 0 \\
\hline 3. & Tool Availability & 0 & 2 & 2 & 1 & 0 \\
\hline 4. & Performance Recognition & 2 & 2 & 2 & 1 & 0 \\
\hline 5. & Promotion of Worker & 1 & 2 & 1 & 0 & 1 \\
\hline & Total & 5 & 10 & 8 & 5 & 2 \\
\hline
\end{tabular}

Source: Field Survey 2020 


\section{Correlation Analysis}

4.3: Determination of the Coefficient of Correlation (r).

\begin{tabular}{|l|l|l|l|l|l|l|l|l|l|}
\hline $\mathbf{X}$ & $\mathbf{Y}$ & $\mathbf{X}^{\mathbf{2}}$ & $\mathbf{Y}^{2}$ & $\mathbf{X Y}$ & $\mathbf{D F}$ & $\mathbf{S L}(\mathbf{r})$ & $\begin{array}{l}\text { Critical } \\
(\mathbf{r})\end{array}$ & $\begin{array}{l}\text { Cal } \\
(\mathbf{r})\end{array}$ & Decision rule \\
\hline 6 & 5 & 36 & 25 & 30 & & & & & \\
\hline 13 & 10 & 169 & 100 & 130 & & & & & \\
\hline 12 & 8 & 144 & 64 & 96 & 3 & $5 \%$ & 0.87 & 0.89 & Ho: Rejected \\
\hline 6 & 5 & 36 & 25 & 30 & & & & & \\
\hline 5 & 2 & 25 & 4 & 10 & & & & & \\
\hline $\mathbf{4 2}$ & $\mathbf{3 0}$ & $\mathbf{4 1 0}$ & $\mathbf{2 2 2}$ & $\mathbf{2 9 6}$ & & & & & \\
\hline
\end{tabular}

$$
\begin{aligned}
& \mathrm{r}=\frac{\mathrm{n}\left(\sum X Y-\left(\sum X^{1}\right)\left(\sum Y\right)\right.}{\sqrt{n\left(\sum X^{2}-\left(\sum X\right)^{2} n\left(\sum Y^{2}\left(\sum Y\right)^{2}\right.\right.}} \\
& \mathrm{r}=\frac{5(296)-(42)(30)}{\sqrt{\left.5(410-42)^{2} 5(222-30)^{2}\right)}} \\
& \mathrm{r}=\frac{1480-1260}{\sqrt{(2050-1764)(1110-900)}} \\
& \mathrm{r}=\frac{220}{\sqrt{(286)(210)}} \\
& \mathrm{r}=\frac{220}{\sqrt{60060}}
\end{aligned}
$$

$$
\begin{aligned}
& r=\frac{220}{245} \\
& r=0.89
\end{aligned}
$$

\section{Decision rule}

$\mathrm{d} / \mathrm{f}=\mathrm{N}-2$

$\mathrm{d} / \mathrm{f}=5-2=3$

$\mathrm{r}=$ critical value at $5 \%=0.87$

When correlation coefficient (r) was applied on the generated data, $r$ critical of 0.87 and $r$ calculated of 0.89 at the degree of freedom 3, at $5 \%$ level of significant were obtained respectively. Thus $\mathrm{r}$ critical value $0.87<\mathrm{r}$ calculated value 0.89 ; thus, result, $\mathrm{H}_{0}$ is rejected. 
Therefore, there is a significant relationship between political environment and efficiency of small scale Enterprise.

\section{Hypothesis 2}

$\mathrm{H}_{0}$ : There is no significant relationship between Political environment and Customers Satisfaction.

Table 4:4: Summary of Percentage Score for Political environment.

\begin{tabular}{|c|c|c|c|c|c|c|}
\hline & Variables & $\mathbf{S A}$ & $\mathbf{A}$ & $\mathbf{U}$ & $\mathbf{D}$ & SD \\
\hline 1. & $\begin{array}{|ll|}\text { Risk and } & \text { Business } \\
\text { Performance } & \end{array}$ & 2 & 2 & 1 & 1 & 2 \\
\hline 2. & $\begin{array}{l}\text { Crisis in Business } \\
\text { Environment }\end{array}$ & 2 & 2 & 1 & 1 & 1 \\
\hline 3. & $\begin{array}{l}\text { Instability in our } \\
\text { Environment }\end{array}$ & 2 & 2 & 1 & 1 & 3 \\
\hline 4. & Kidnapping Challenges & 2 & 3 & 3 & 1 & 3 \\
\hline 5. & Killing Challenges & 2 & 1 & 2 & 2 & 3 \\
\hline & Total & 10 & 10 & 8 & 6 & 12 \\
\hline
\end{tabular}

Source: Field Survey 2020

Table 4:5: Summary of Percentage Score for Efficiency.

\begin{tabular}{|c|l|c|c|c|c|c|}
\hline \multicolumn{1}{|c|}{ Variables } & SA & A & U & D & SD \\
\hline 1. & Suitable Environment & 2 & 2 & 1 & 1 & 1 \\
\hline 2. & On Time Delivery & 2 & 2 & 1 & 2 & 1 \\
\hline 3. & Motivation & 1 & 1 & 2 & 0 & 2 \\
\hline 4. & $\begin{array}{l}\text { Potential } \\
\text { Acknowledgment }\end{array}$ & 1 & 1 & 1 & 1 & 2 \\
\hline 5. & $\begin{array}{l}\text { Term of Agreement } \\
\text { Keeping }\end{array}$ & 2 & 1 & 3 & 1 & 2 \\
\hline & \begin{tabular}{l} 
Total \\
\hline
\end{tabular} & 7 & 8 & 5 & 8 \\
\hline
\end{tabular}

Source: Field Survey 2020 


\section{Correlation Analysis}

4.6: Determination of the Coefficient of Correlation ( $r$ ).

\begin{tabular}{|c|l|l|l|l|l|l|l|l|l|}
\hline $\mathbf{X}$ & $\mathbf{Y}$ & $\mathbf{X}^{\mathbf{2}}$ & $\mathbf{Y}^{\mathbf{2}}$ & $\mathbf{X Y}$ & $\mathbf{D F}$ & $\mathbf{S L}(\mathbf{r})$ & $\begin{array}{l}\text { Critical } \\
(\mathbf{r})\end{array}$ & $\begin{array}{l}\text { Cal } \\
(\mathbf{r})\end{array}$ & $\begin{array}{l}\text { Decision } \\
\text { rule }\end{array}$ \\
\hline 10 & 8 & 100 & 64 & 80 & & & & & \\
\hline 10 & 7 & 100 & 49 & 70 & & & & & \\
\hline 8 & 8 & 64 & 64 & 64 & 3 & $5 \%$ & 0.87 & 1.29 & Ho: Rejected \\
\hline 6 & 5 & 36 & 25 & 30 & & & & & \\
\hline 12 & 8 & 144 & 64 & 96 & & & & & \\
\hline $\mathbf{4 6}$ & $\mathbf{3 0}$ & $\mathbf{4 4 4}$ & $\mathbf{2 9 8}$ & $\mathbf{2 8 0}$ & & & & & \\
\hline
\end{tabular}

$$
r=\frac{\mathrm{n}\left(\sum X Y-\sum X^{1}\left(\sum Y\right)\right.}{\sqrt{n\left(\sum X^{2}-\left(\sum X\right)^{2} n\left(\sum Y^{2}\left(\sum Y\right)^{2}\right.\right.}}
$$

$$
\begin{aligned}
& r=\frac{5(280)-(46)(30)}{\sqrt{\left.5(444)-(46)^{2} 5(298)-(30)^{2}\right)}} \\
& r=\frac{1400-1380}{\sqrt{(2220-2116)(1490-900)}} \\
& r=\frac{20}{\sqrt{(104)(590)}} \\
& r=\frac{320}{\sqrt{61360}}
\end{aligned}
$$

$$
\begin{aligned}
& r=\frac{20}{22} \\
& r=0.90
\end{aligned}
$$

\section{Decision rule}

$$
\begin{aligned}
& \mathrm{d} / \mathrm{f}=\mathrm{N}-2 \\
& \mathrm{~d} / \mathrm{f}=5-2=3 \\
& \mathrm{r}=\text { critical value at } 5 \%=0.87
\end{aligned}
$$


Having applied correlation coefficient $r$, calculated value of $0.90<$ critical value of 0.87 were obtained respectively. Therefore, alternative hypothesis retained and null hypothesis accepted. There is a significant relationship between the variables.

\section{Hypothesis 3}

$\mathrm{H}_{0}$ : There is no significant relationship between political environment and employee retention

Table 4:7: Summary of Percentage Score for Political environment.

\begin{tabular}{|c|c|c|c|c|c|c|}
\hline & Variables & $\mathbf{S A}$ & $\overline{\mathbf{A}}$ & $\overline{\mathbf{U}}$ & $\mathbf{D}$ & SD \\
\hline 1. & \begin{tabular}{|l|} 
Risk and Business \\
Performance
\end{tabular} & 5 & 1 & 2 & 4 & 2 \\
\hline 2. & $\begin{array}{l}\text { Crisis in Business } \\
\text { Environment }\end{array}$ & 3 & 1 & 1 & 3 & 1 \\
\hline 3. & $\begin{array}{l}\text { Instability in our } \\
\text { Environment }\end{array}$ & 4 & 1 & 2 & 4 & 1 \\
\hline 4. & Kidnapping Challenges & 4 & 1 & 1 & 2 & 1 \\
\hline 5 . & Killing Challenges & 2 & 1 & 2 & 2 & 1 \\
\hline & Total & 18 & 5 & 8 & 15 & 6 \\
\hline
\end{tabular}

Source: Field Survey 2020

Table 4:8: Summary of Percentage Score for Efficiency.

\begin{tabular}{|c|l|c|c|c|c|c|}
\hline \multicolumn{1}{|c|}{ Variables } & SA & A & U & D & SD \\
\hline 1. & Prompt Salary Payment & 2 & 0 & 3 & 4 & 1 \\
\hline 2. & $\begin{array}{l}\text { Conducive Working } \\
\text { Environment }\end{array}$ & 3 & 1 & 2 & 2 & 0 \\
\hline 3. & Team Work & 3 & 1 & 1 & 2 & 0 \\
\hline 4. & Good Relationship & 4 & 1 & 0 & 3 & 1 \\
\hline 5. & Organizational Culture & 3 & 1 & 2 & 3 & 1 \\
\hline & Total & 15 & 4 & 8 & 14 & 3 \\
\hline
\end{tabular}

Source: Field Survey 2020 


\section{Correlation Analysis}

4.9: Determination of the Coefficient of Correlation ( $r$ ).

\begin{tabular}{|c|l|l|l|c|l|c|c|l|l|}
\hline $\mathbf{X}$ & $\mathbf{Y}$ & $\mathbf{X}^{\mathbf{2}}$ & $\mathbf{Y}^{\mathbf{2}}$ & $\mathbf{X Y}$ & $\mathbf{D F}$ & $\mathbf{S L}(\mathbf{r})$ & $\begin{array}{c}\text { Critical } \\
(\mathbf{r})\end{array}$ & $\begin{array}{l}\text { Cal } \\
(\mathbf{r})\end{array}$ & $\begin{array}{l}\text { Decision } \\
\text { rule }\end{array}$ \\
\hline 18 & 15 & 324 & 225 & 270 & & & & & \\
\hline 5 & 4 & 25 & 20 & 20 & & & & & \\
\hline 8 & 8 & 64 & 64 & 64 & & & & & \\
\hline 15 & 14 & 225 & 196 & 210 & 3 & $5 \%$ & 0.87 & 0.95 & $\mathrm{H}_{\text {O: } \text { Rejected }}$ \\
\hline 6 & 3 & 36 & 9 & 18 & & & & & \\
\hline 52 & 44 & 674 & 514 & 582 & & & & & \\
\hline & & & & & & & & & \\
\hline & & & & & & & & & \\
\hline
\end{tabular}

$$
r=\frac{\mathrm{n}\left(\sum \mathrm{XY}-\sum \mathrm{X}^{1}\left(\sum Y\right)\right.}{\sqrt{n\left(\sum X^{2}-\left(\sum X\right)^{2} n\left(\sum Y^{2}-\sum Y\right)^{2}\right.}}
$$

$r=\frac{5(582-(52)(44)}{\sqrt{5(444-52)^{2} 5(298-44)^{2}}}$

$$
\begin{gathered}
r=\frac{2779-2562}{\sqrt{(3370-2704)(2570-1936)}} \\
r=\frac{622}{\sqrt{(666)(634)}} \\
r=\frac{622}{\sqrt{422244}}
\end{gathered}
$$

$r=\frac{622}{649}$

$$
\mathrm{r}=0.95
$$

Decision rule

$\mathrm{d} / \mathrm{f}=\mathrm{N}-2$

$\mathrm{d} / \mathrm{f}=5-2=3$

$\mathrm{r}=$ critical value at $5 \%=0.87$ 
With the use correlation coefficient $r$, calculated value of 0.95 and critical value of 0.87 was obtained accordingly $(0.95>0.87)$. Because higher value of the calculated value was obtained, we accept the alternative and reject the null hypothesis.

\section{Findings}

Data analyzed revealed that efficiency of small scale industries is dependent and sensitive to political environment. This is indication that inefficiency of small scale enterprises could results from political instability. The finding is in consonance with the finding of Nwaeke (2012) who asserts that absolute responsibility of the management and organization is to adopt methods of adapting reasonably to the political environmental changes in order for them to survive effectively and efficiently.

Another finding is that political environment influences and brings about customer satisfaction. This corresponds with the ideas of Raja et al (2014) who opines that there is a relationship between environmental factors and customer satisfaction. Alaezi (2009) also states that work environment influences service climate which in turn influences employee job satisfaction and customer satisfaction.

Again, from the data analyzed, it was discovered that stable political environment encourages job satisfaction and employee retention in an organization. This agrees with the opinion of Ali et al (2013) that working condition is significantly related to employee productivity and employee retention. Daisy (2013) also postulates that work environment condition has a positive relationship with employee retention.

\section{Conclusion}

In fact, efficiency and customer satisfaction are critical to all success of an organization (private and public) and no organization anywhere in the world excels with inefficient performance and customers dissatisfaction. Therefore, based on the findings, we conclude that there is a positive correlation that exists between political environment, efficiency of organizational performance and customer satisfaction.

We also further conclude that there is a significant relationship between political environment and employee retention in an organization. It suggests that if the issue of political instability and crisis is not addressed or taken seriously by organization, there is going to be customer dissatisfaction and employee turnover in an organization.

\section{Recommendations}

Having examined political environment and organizational performance with respect to selected small and medium scale enterprises in Delta State, it is crystal clear that growth and development of small and medium scale enterprises (SMEs) to a very large extent rest on good and stable political environment. But majority of small business owners are ignorant and nonchalant of what stable political environment is all about, both trading and manufacturing organization. Based on the foregoing, we recommend as follows:

1. According to Nwaeke (2011), environmental consciousness enhances entrepreneurial success and efficiency. Entrepreneurs must be conscious of political changes of the business environment.

2. There should be constant monitoring and conducting of environmental scanning always to maintain customer satisfaction (Adeoye and Elegunde, 2012).

3. Retention of employee in an organization is not guaranteed under unstable political environment. We recommend that organizations should adapt to environmental changes of the business environment. 


\section{References}

Aborode, B (2005). Strategic Financial Management. Lagos Corporate publishers.

Alaezi, O. (2009). New Dimensions in Entrepreneurship. Spectrum Book Limited publishers, Rign Road, Benin City.

Aldrich, H. (1979). Fundamental as Moderate of Job Satisfaction, New York Random House incorporation.

Alexender, D; and Britton, A; (2000). Financial Reporting; $5^{\text {th }}$ Ed. London: Thomas Learning publishing.

Ali yassin, S.A; Abdiaziz, A.A and Aboiqani.A.A (2013). Working Condition and Employees Productivity in Manufacturing Companies in Sub-Sahara African context: Case of Somali, Educational Research International, 2(2).

Allen, D. R and Willbrun, M. (2012). "Linking Customer and Employee Satisfaction to the Bottom-line" A comprehensive guide to establishing the impact of customer and employee satisfaction or critical business outcome. ASQ quality press USA.

Aluko, O. A; and Adeusi, S. O (2014) .Assessing The Role Of Government in Promoting Small Scale Business in Kogi State. The Kabba/Bunu Experience. Journal of Business and Management (10 SR - JBM)

Amaechine, H.O and Nnadozie, B.M. (1995). Entrepreneurship concept of small business management. Theo Onwuka and Sons Publishers, Oguta, road Onitsha, Anambra State.

Amstrong, M; and murlis, H. (2007). Reward Management. A handbook of remuneration strategy and practices. Revised $5^{\text {th }}$ edition, Kogan page limited.

Anderson, E. W and Fornel, C. (1994). A Customer Satisfaction Research Prospectus and Practice (Ed) C. A. Sage.

Andoh, C. H. (2007). Competing Effectively: Environmental Scarning, Competitive Strategy and Organization Performance in Small Manufacturing Firms. Journal of Small Business Management. 18(1)

Bharedwaj G. S. (2009). Customer Satisfaction and Stock Return Risk. Research collection Lee Kong Chain School of Business Singapore Management University

Brunilda, D: and Elano, M (2015). Factors Influencing the Bank profitability -Empirical Evidence from Albania: Asia Economic and Financial Review S (3): 483 - 494

Chaminade, B. (2007). A Retention Checklist. How do you rate? www.human resources magazine.co.au

Chittithaworn, C; Islam, M. A; Keavichana, T; and Yusuf, D. H. M (2011). Factors Affecting Business Success of Small and Medium Enterprises (SMEs) in Thailand, Asian Social Science 7 (5) pp 180

Chuan, and Fei, P (2009). The Impact of Customer Satisfaction Unprofitability. A study of State owned enterprises in China. 
Corina, G. Liviu, I and Roxana, S. (2011). Determinant of organizational performance. The case of Romanic management and marketing challenges for the knowledge society Vol.6 No.2.

Daft, R.L (2000). Organization theory and Design (7th edition) south Western College Publishing, Thompson Learning, U.S.A.

Demaki, G. O. K (1999). The Environment of Business. A programmed Text (first edition).

Ecker, S. C. (2007). Inventory Management and its Effect on Customer Satisfaction. Journal of Business and Public policy (1) $1-2$.

Eruemgbe, G. O. (2015). Impact of Business Environment on Organization Performance in Nigeria. A study of Union Bank of Nigeria, European Scientific Journal, 2015.

Galo, N. D (2015). The impact of Nigeria Business Environ on Company Performance: A Case of most capital; based Companies in Nigeria. International Journal of Business and Management review, Vol 3 No 4 pp. 36 - 48.

Gome, C. and Spencer, J.W. (2002). Can government Policies Promote Entrepreneurship? Evidence From Clute Uruguay and Costa. Presented at the annual meeting of the Academy of Management Benverico.

Gomez and Spenzer, J. W. (2002). Can Government Policies Promote Entrepreneurship? Evidence from Chite Gruguay and Costa Rica, presented at the Annual meeting of the Academy of management benver co.

Gratchev, M. (2001), Forethought; making the most of cultural differences, Harvard Business Review.

Habid, M and Zurawick, Z. (2002). Corruption and foreign Direct Investment. Journal of International Business Studies, 33.291 -308.

Habid, M. and Leon, Z. (2002). Corruption and foreign Direct Investment. Journal of Internation Business studies, 33; 291-308.

Harun, K; and Hasan, A. (2010). An Empirical Study on Employee Turnover Tendency. TADAIE'S review of public administration, Vol.4. No4

Idomobi, E. I. (2010). Theory and Practice of Management (first edition) Gostak printing and Public co. Ltd Enugu, Nigeria.

Jonson, B (2007) Does the size matter? The Relationship between size and profitability of Iceland firms.

Kinyua, A. N. (2014). Factors Affecting the Performance of Small and Medium Enterprise in the Jua Kalisect in Nakuru Town of Kenya. Journal of Business and Management (IOSR - JBM) Vol. 16 Jan 2014.

Low, J. (2000). The Value Creation Index. Journal of intellectual capital, (13) $252-262$.

Maja, P. and Gospia, V. (2012). Influence of Firm Size on its Business Success: Creation Operational Research Review (CRORR) Vol. 3.

Mamoh, M. A and Aliyu, A. N. (2010). Entrepreneurship and Small Business Management in $21^{\text {st }}$ Century Nigeria, Aboki Publishers, Markurdi. 
Mark, J; and Nwaiwu, J. N: (2015). Impact of Political Environment on Business Performance of Multinational companies in Nigeria: An international Multidisciplinary Journal, Ethipia Vol 9. (3).

Mello, J.A. (2007). Strategic Human Resources Management. $2^{\text {nd }}$ edition, India: Cengage South-western.

Meyer, J.P; and smith L.A (2003). Human Resources Management and Organizational Commitment. Test of a mediation model, Canadian journal of administrative science 17,319-331.

Ministry of Commerce and Industry Asaba, 2013 Delta state business directory, April 2013.

Modh, S. M. N; Peou, G; and Ali, J. (2010). Moderating Effect of Government Policy in Entrepreneurship and Growth performance of small and medium Enterprises in Cambodia. International Journal of Business and Management Sciences 3 (1) 37.

Mohammed, A.A; Mohammed, Tim; and Ghazala, A. (2013). Effect of Performance Appraisal Politics on Job Satisfaction, Turnover Intention and Loyalty to Superior. Study with references to the telecom. Organizations of Pakistan international review of management and business. Research Vol.2. No. 2. No. 3.

Mohammed, U. D; and Nzeribe, C. G (2014). Entrepreneurship Skill and Profitability of Small and Medium Enterprises (SMEs): Resources Acquisition Strategies for new venture in Nigeria proceeding of $25^{\text {th }}$ International Business research conference $13-$ 14 January 2014.

Muende, A. A (2014). Conceptual Model of the Determinant of Performance of Tourism Sector of Small and Medium Enterprises (SMEs): International Journal of Business and Management Invention.

Murthar, T.P. (1991). Swimming Industrial Targeting State and Credibility of law, tenzmics and Regulation

Ndugbu, M. O; Okorji, L and Kdu, A. U (2014). Organizational Politics and Employees Performance in Private Sectors Investment: A comparative study of Zenith Bank Plc and Akon Plc Nigeria European Journal of Business and Management Vol 6. No 26. 2014.

Ngige, C.D. (2016). Entrepreneurship and small Business management. Published May, 2016.

Ngumi, F. N (2015) Inventory Management Practices and Productivity of Large Manufacturing Firms in Nairobi, Kenya.

Nwaeke, I. L. (2012). Environmental Dynamics, Organizational Adaptation and Business Effectiveness in Nigeria. An international Journal of Arts and Humanities, Bahir, Dar, Ethiopia Vol. 2 (2).

Nwaorgu, I.A. (2008). The Impact of Financial Institutions on small scale Enterprises in the Nigerian Economy. Journal of Management Sciences (JMS). Faculty of management sciences, Nnambra State University, Uli.

Oghojafor, B.E.A; Kuye, O.L; Ogunkoya, O.A; and Shobayo, P.B. (2014). Competitive strategies, Technological capabilities and Organizational performance: Evidence from Nigeria manufacturing Industry, Arabian Journal of Business and Management 
Review (Nigeria chapter) Vol.2.No.1, 2014.

Ogundele, O. J. K (2005). Management and Organization "Theory and Behaviour" stable Book services, Lagos, Nigeria.

Olusanya, S. O; Awotungase, S. A. and Ohadebere, E. C. (2012). Effective planning and organizational productivity: (A case study of sterling bank Nigeria, Plc)

Oyebanj J. (1994) Nigeria Business Environment and Organization Effectiveness; Abiola Bookshop Linibil.

Oyebanji, J. (1994). Nigeria Business Environment and organizational effectiveness, Abiola Bookshop Limited.

Pearson II, J. A; Robinson, Jr R. B. and Mite, A (2008). Strategic Management Formulation Implementation and Control Data McGraw Hill.

Porter, M. E. (1985) Competitive Advantage: Creating and sustaining superior performance. New York, Nig. Free pass.

Rad, H. (2008). Lead Time Revolution. A case study of Bead Etikett and system AB.

Rehman, K; Sail, N; Khen, A and Nawaz, A (2013). Impact of Job Satisfaction on Organizational Commitment: A Theoretical Model for Academicians in HEL of developing countries like Pakistan. International Journal of Academic Research in Accounting, Finance and Management Sciences 3(1).

Richard, O. and Wada, D. (2001). Corporate Performance Management. How to build a better organization through measurement Driven strategies Alignment Butter worth Heineman.

Scott, N.R and David, G. (2007). Organization: Rational, Natural and Spen system; (5th Edition), upper Saddle River, NJ: Prentice Hall.

Sutherland, M.M (2004). Factors Affecting the Retention of Knowledge Workers. (PH.D Dissertation). Faculty of Economics and Management Sciences, University of Johannesburg.

Wyse, S. E (2012) Customer Satisfaction and Customer Loyalty: http://www. snap.survey .com/blog/customer/ satisfaction- customer loyalty. 